\title{
Performance of marron (Cheraxcainii) origin probiotic Bacillus mycoides in earthen commercial marron ponds
}

\begin{abstract}
The present study evaluated the performance of marron (Cheraxcainii) origin probiotic Bacillus mycoides post laboratory scale trials by measuring total haemocyte counts (THC),hepatosomatic indices (HSi), intestinal bacteria population, gluthathionine peroxide (GPx) enzyme activity, and survival rate (SR)of marron.

The probiotic was supplemented to a commercial marron feed (used as basal diet) at $108 \mathrm{CFU} / \mathrm{mL}$ and given to marron during eleven months feeding trial using a commercial marron ponds $\left(10 \times 15 \mathrm{~m}^{2}\right)$. The ponds were stock with marron juveniles at 3000/pond. The probiotic feed was prepared weekly to ensure its freshness and viability, then kept in refrigerator before using.

The results suggested the THC, His andthe intestinal bacteria population of marronfed probiotic supplemented diet were significantly higher $(\mathrm{P}<0.05)$ compared to THC, HSi and intestinal bacteria population of basal diet fed marron both on day 90th and day 160th. The GPx enzyme activity was detected also significantly higher $(\mathrm{P}<0.05)$ in marron fed with the probiotic diet both on day 90th and termination of the feeding trial.At termination of the trial, survival ofmarron fed a diet supplemented probiotic was significantly higher $(74.80 \pm 2.52 \%)$ than that of marron fed a basal $\operatorname{diet}(66.15 \pm 6.33 \%)$.

In brief, the customized marron origin probiotic B. mycoides worked effectively in vivo (commercial marron ponds) as indicated by a significant improvement of marron immunity and health status (THC, GPx enzyme activity, intestinal bacteria population and HSi) which in turn enhanced survival rates when compared to basal diet fed marron.
\end{abstract}

Volume 8 Issue 6 - 2019

\author{
Irfan Ambas,' Ravi Fotedar, ${ }^{2}$ Nicky Buller ${ }^{3}$ \\ 'Department of Fishery, Faculty of Marine Science and Fishery, \\ Indonesia \\ ${ }^{2}$ Department of Environment and Agriculture, Sustainable \\ Aquatic Resources and Biotechnology, Australia \\ ${ }^{3}$ Department of Agriculture and Food Western Australia, Animal \\ Health Laboratories, Australia
}

\begin{abstract}
Correspondence: Irfan Ambas, Department of Fishery, Faculty of Marine Science and Fishery, Hasanuddin University, Indonesia, Emailirfanamba@yahoo.com
\end{abstract}

Received: December 04, 2019 | Published: December 20, 2019

Keywords: marron, probiotic, THC, HSi, SR

Abbrevations: HSi, hepatosomatic indices; THC, total haemocyte counts; GPx, gluthathionine peroxide

\section{Introduction}

Today, it has been widely accepted that probiotics play a significant role in aquaculture ${ }^{1-4}$ as an ecofriendly methodfor disease control for sustainable aquaculture, ${ }^{5}$ however there has been only a few in vivo studies on the use of probiotics in a controlled environment. ${ }^{6}$ In screening a probiotic candidate, an in vivo test is essential ${ }^{7-10}$ as in vivo physiology is more complex and different from in vitro monoculture ${ }^{6}$ No study has ever compared probiotic beneficial effectsin vitro and in vivo. ${ }^{11}$

The complexities encountered by an added probiotic under outdoor conditions include (i) the uncertainty for the probiotic to remain viable in an aquatic environment ${ }^{3}$ (ii) interaction with other strains in the host environment ${ }^{12,13}$ (iii) selection process by the host gastrointestinal $\operatorname{tract}(\mathrm{GIT})^{14}$ (iv) competition with the indigenous GIT inhabitants ${ }^{10}$ (v) viability during storage. ${ }^{15}$ To complicate the issue, not all of the authors examined the viability of the probiotics during the feed preparations after the microbial cells have been added to the fee. ${ }^{3}$ For these reasons, the marron origin (host GIT and its environment) with favourable probiotic properties is preferable by most of the authors for an ideal candidate $e^{1,2,7,16-18}$ as its efficacy is likely to be highest in the host and particularly in its natural environment. ${ }^{7,19}$

Bacillusmycoidesis a predominated bacterium isolated from a number of healthy adult farmed marron GIT that exhibit favourable probiotic properties such as non-pathogenicity to marron, antagonism ability towards common crayfish pathogens (Vibrio mimicus and $V$. cholerae non-01), exhibition of a diverse enzyme profiles and nonsusceptible to the majority of antibiotics tested ${ }^{20}$ improved immunity ${ }^{21}$ and the gastrointestinal health status of marron. ${ }^{22}$

To date, evaluating probiotic performance in vivo studies is limited to tiger shrimp Penaeusmonodon, ${ }^{23}$ shrimp Litopenaeusvannamei ${ }^{24}$ and beluga Husohuso. ${ }^{25}$ When evaluating probioticsin vivo for its nutritional benefit outcomes in aquatic animals, the probiotic candidates should be added to the diet and its effect evaluated on the growth and/or physiological status of the animals. ${ }^{7}$ The present study examined in vivo performance of customized probiotic $B$ mycoides in commercial marron ponds by counting the total haemocyte (THC), hepatosomatic indices (HSi), intestinal bacteria population, gluthathionine peroxide (GPx) enzyme activity, survival rate and marron pond productivity. 


\section{Materials and methods}

\section{a. Experimental marron farm site}

The present study was conducted at an existing commercial marron farm located at 432 Boorara Road, Nortchcliffe Western Australia 6262 (Latitude $-34.66001 \mathrm{~N}$; Longitude 1169'49.644W). Six of the $900 \mathrm{~m}^{2}$ existing commercial marron ponds with an average depth of between $1.6 \mathrm{~m}$ to $1.7 \mathrm{~m}$ were used for the dietary supplemented probioticfeeding trial. As the marron production operation in these commercial ponds was already underway before the commencement of the trial, the commencement of this feeding trial was reflected by shifting the existing marron diets to the test diets (probiotic $B$. mycoides supplemented diet and the basal diet).

\section{b. Preparation of the diet and feeding}

The commercial marron diet supplied by specialty feeds, Glen Forrest Western Australia was used as a basal diet, which was used during previous laboratory scale studies. The proximate composition of the basal diet was: $26 \%$ crude protein, $9 \%$ crude fat and $5 \%$ crude ash.

Supplementation of the probiotic to the basal diet followed the established method. ${ }^{26} \mathrm{~A}$ pure colony of the isolate was grown on blood agar (BA) plates and incubated overnight at $25^{\circ} \mathrm{C}$. The overnight growth inoculum was diluted into $20 \mathrm{~mL}$ of sterilized normal saline before being sprayed onto the basal diet at a concentration of $108 \mathrm{CFU} / \mathrm{g}$ of feed and then immediately covered with aluminium foil and stored in a refrigerator at $4{ }^{\circ} \mathrm{C}$ to avoid bacterial growth. The probiotic was supplemented at $108 \mathrm{CFU} / \mathrm{g}$ of feed and performed on a weekly basis to maintain freshness.

The concentration $(\mathrm{CFU} / \mathrm{mL})$ of the probiotic bacterium sprayed onto the feed was determined using an established $\operatorname{method}^{27}$ where optical density (Spectrophotometer, BOECO S-20, Hamburg, Germany) correlates to the bacterial concentration $(\mathrm{CFU} / \mathrm{mL})$ and confirmed by performing a total bacterial count using BA plates. ${ }^{28}$

Feeding was performed once per day in the late afternoon and adjusted weekly after weight sub-sampling of the marron from each pond, which referred to demand feeding rates obtained from The Second Pemberton Grow Out data set 1990-1993, Department of Fisheries Western Australia.

\section{c. Data collection}

Most of the parameters measured in the present study useda comparable size of the two treatment groups such as hepatosomatic indices (HSi), intestinal bacteria population, total haemocyte counts (THC), gluthathionine peroxide (GPx) enzyme activity, except for the survival rates andmarron productivity in marron pond.

Data collection was performed at day 90th, day 160th and at the harvest (day 310th) for determination of the survival rate, pond production and GPx enzyme activity.

\section{d. Total haemocyte counts (THC)}

The total haemocyte count was measured following the established methods used for western rock lobsters Panuliruscygnus. ${ }^{29}$ The haemocyte samples preparation was performed on the farm site and mixed with an anticoagulant at a ratio of $1: 1$, injected into $2 \mathrm{~mL}$ cuvette tubes then kept in an iced cool box before taking to the laboratory for THC determination.
In brief, $0.5 \mathrm{~mL}$ of haemolymph and anticoagulant mixture was inserted into a haemocytometer (The Neubauer Enhanced Line, Munich, Germany) counting chamber and immediately viewed under 100-fold magnification on a camera-equipped microscope and images were taken for THC. Subsequently, the cells were counted in both grids, and the mean was used as the haemocyte count.The total haemocyte count was calculated as $\mathrm{THC}=($ cells counted $\mathrm{x}$ dilution factorx 1000)/volume of grid $\left(0.1 \mathrm{~mm}^{3}\right)$.

\section{e. Hepatosomatic indices (HSi)}

The hepatosomatic index (HSi) of marron fed basal and B. mycoides supplemented diets were calculated as per established equations $s^{30,31}$ In brief, the hepatopancreas of marron from each treatment group were removed, placed in foil and weighed. Determination of the hepatosomatic indices (HSi) used the following equation;

$\mathrm{HSi}=\mathrm{Wwhx} 100 \mathrm{Wt}-1$ Where;

$\mathrm{HSi}=$ Wet hepatosomatic indices $(\%)$

Wwh=Weight of wet hepatopancreas $(\mathrm{g})$

$\mathrm{Wt}=$ Total weight of marron $(\mathrm{g})$

\section{f. Intestinal bacteria population(million CFU g-1 of gut)}

The intestinal bacterial population of marron from the different feeding groups was determined following our previous work. ${ }^{22}$ Before aseptic removal of the GIT, the marron was anaesthetized by placing the animal at $-20^{\circ} \mathrm{C}$ for 5 minutes. Subsequently, the dorsal shell was cut-off from tail to head until the intestines were exposed, then the intestine was collected and placed in a sterilised pestle, weighed and homogenised. The homogenates of intestines were diluted serially (from 10-1 to 10-6) using a sterile normal saline. Fifty microliters of each serial dilution was inoculated onto a blood agar (BA) plate and incubated overnight in a $\mathrm{CO} 2$ incubator at $25^{\circ} \mathrm{C}$. A colony count was performed for each dilution to determine the total number of aerobic bacteria. $^{28}$

\section{g. Gluthathionine peroxide enzyme activity}

The gluthathionine peroxide enzyme activity was determined followed the established method..$^{32}$ In brief, the marron muscle tissue was diluted with a physiological saline at a ratio of 1:1 and stored at $4^{\circ} \mathrm{C}$ until used.To calculate GPxactivity, $0.2 \mathrm{~mL}$ muscle tissue homogenates (homogenized in $0.4 \mathrm{M}$ sodium phosphate buffer, $\mathrm{pH}$ 7.0), $0.1 \mathrm{~mL} 10 \mathrm{mM}$ sodium azide, $0.2 \mathrm{~mL} 0.2 \mathrm{mM}$ reduced glutathione, and $0.1 \mathrm{~mL} 0.2 \mathrm{mM}$ hydrogen peroxide were mixed, then incubated for 10 minutes at $37^{\circ} \mathrm{C}$ after which $0.4 \mathrm{~mL}$ of $10 \%$ trichloroacetic acid (TCA) was added to stop the reaction.Subsequently, the mixtures were centrifuged at $3200 \mathrm{rpm}$ for 20 minutes. The supernatant was assayed for glutathione content using Ellman's reagent $(9.8 \mathrm{mg}$ 5,5'-dithiobis-[2-nitrobenzoic acid] [DTNB] in $100 \mathrm{~mL} 0.1 \%$ sodium citrate). The GPx enzymes activity of the samples was measured at the Biochemistry Laboratory, Department of Agriculture and Food, Western Australia. The GPx activity was expressed as micrograms of GSH consumed per minute per milligram of protein.

\section{h. Survival rate $(\%)$ and pond production}

The survival rate of marron from each pond and treatment group was measured using the established equation as follows;

$$
S R(\%)=N t / N o \times 100
$$


Where;

$\mathrm{SR}=$ survival rate $(\%)$

$\mathrm{Nt}=\mathrm{No}$ of marron at measurement (ind)

$\mathrm{No}=\mathrm{No}$ of marron at initial stocking

In addition, the pond production from each pond was determined by counting and weighing total marron at harvest using the following equation;

\section{Pond production $\left(\mathrm{kg} / \mathrm{m}^{2}\right)=$ Total weight $(\mathrm{kg}) /$ pond size $\left(\mathrm{m}^{2}\right)$}

Whereas the average marron weight at harvest was calculated as follow;

Mean weight $(\mathrm{g})=\mathrm{Tw} / \mathrm{Tn}$

Where Tw=total weight of marron each pond $(\mathrm{g})$

$\mathrm{Tn}=$ Total number of marron (ind)

\section{i. Temperature $\left({ }^{\circ} \mathrm{C}\right)$}

The temperature fluctuation was recorded by placing a temperature data logger (Onset HOBO) in each pond.In addition, each pond was equipped with two paddle wheels to ensure sufficient dissolved oxygen especially during critical periods.

\section{j. Data analysis}

The data were analysed using T-test Microsoft Excel for windows version 2010. The difference of means between the two treatment groups was determined at 0.05 levelof significance.

\section{Results}

\section{k. Total haemocyte counts (THC)}

TheTHC of marron fed basal and probiotic, B. mycoides supplemented diets was not significantly different $(\mathrm{P}>0.05)$ at day 90th of marron rearing, however on day 160ththe THC ofprobiotic diet fed marron was significantly higher $(\mathrm{P}<0.05)$ than the THC of basal diet fed marron (Figure 1).

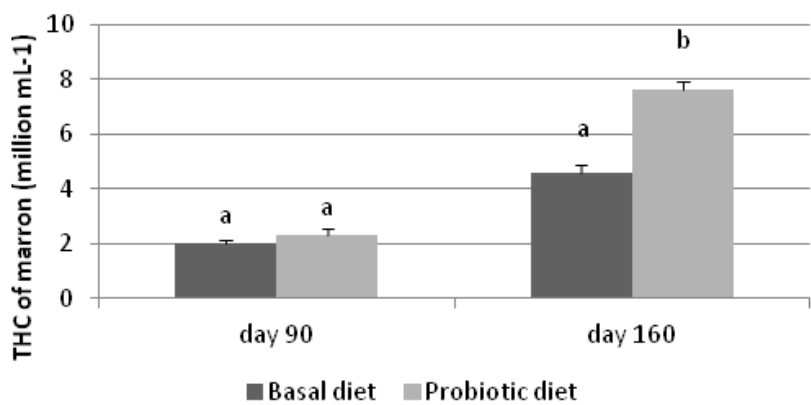

Figure I THC of marron (million cells $\mathrm{mL}^{-1}$ ) fed basal and probiotic diets. *Different letters over bars indicates significantly different at 0.05 .

\section{l. Wet hepatosomatic indices (\%)}

In the present study, the wet hepatosomatic indices (HSi) of probiotic diet fed marron was significantly higher $(\mathrm{P}<0.05)$ both at day $90^{\text {th }}$ and day $160^{\text {th }}$ of measurements (Figure 2) than the HSi of basal diet fed marron. The HSi of basal diet fed marron was lower at day $90^{\text {th }}$ than the HSi at day $160^{\text {th }}$.

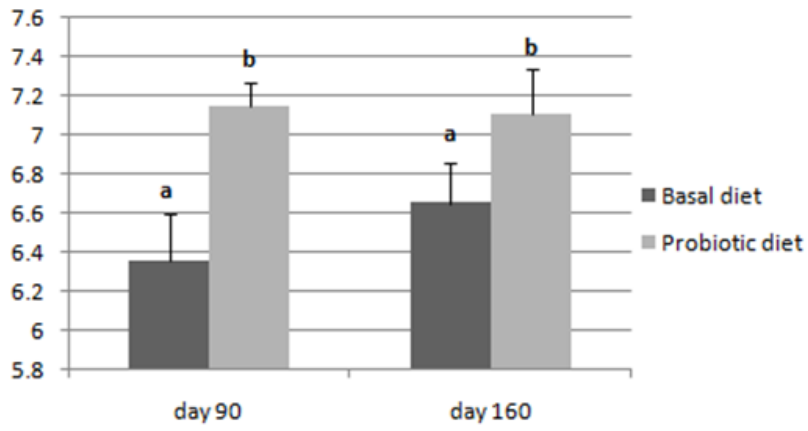

Figure 2 Hepatosomatic indices (HSI) of marron fed basal and probiotic diets. *Different letters over bars indicates significantly different at 0.05 .

\section{m. Intestinal bacteria population (million $\mathrm{CFU} / \mathrm{g}$ of gut)}

Supplementation of a marron-origin probiotic, B. mycoidesto thediet significantly $(\mathrm{P}<0.05)$ improved the intestinal bacteria population of marron compared to intestinal bacteria population of the basal diet fed marron, both on day $90^{\text {th }}$ and day $160^{\text {th }}$. In addition, there is an increase of intestinal bacteria population in both treatment groups on day $160^{\text {th }}$ compared to day $90^{\text {th }}$ (Figure 3 ).

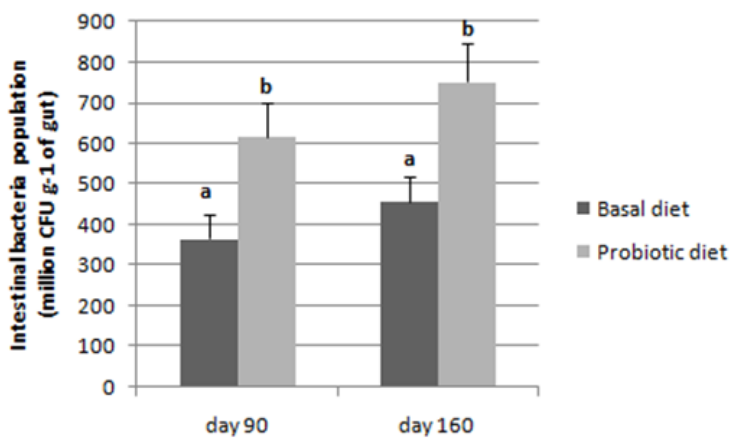

Figure 3 Intestinal bacteria population of basal and probiotic diets fed marron. *Different letters over bars indicates significantly different at 0.05 .

n. Gluthathionine peroxide (GPx) enzyme activity of tissue muscle

The GPx enzyme activity was significantly higher $(\mathrm{P}<0.05)$ in the marron tail muscle tissue fed with the probiotic $B$. mycoides supplemented diet compared to the GPx acitivity of basal diet fed marron both on day $90^{\text {th }}$ and termination of the feeding trial (Figure4).

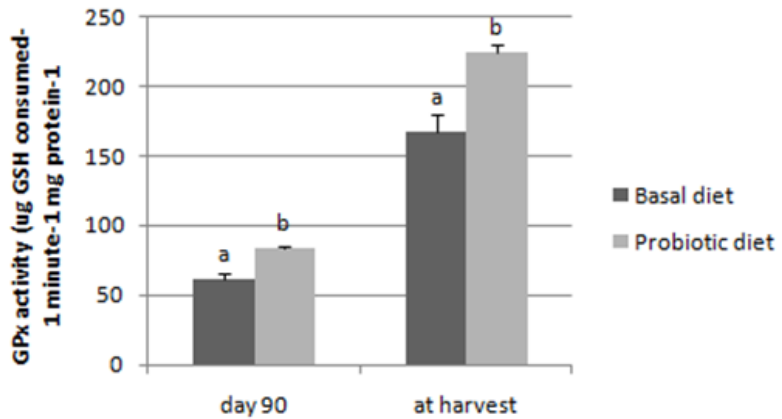

Figure 4 GPx enzyme activity in tissue muscle of basal and probiotic diets fed mar.

*Different letters over bars indicates significantly different at 0.05 . 


\section{o. Survival rate (\%) and pond production $\left(\mathrm{kg} / \mathrm{m}^{2}\right)$}

The present study demonstrated that the survival rate $(\%)$ of probiotic fed marron ranged between $74.80 \pm 2.52$ (\%), which was significantly higher $(\mathrm{P}<0.05)$ than the survival rate of marron from the ponds fed with basal diets $(66.15 \pm 6.33 \%)$.

Meanwhile, the average pond production of the basal diet was $258.3 \pm 32.6 \mathrm{~g} / \mathrm{m}^{2}$ whereas the average pond production of the probiotic diet fed marron was $215 \pm 26.1 \mathrm{~g} / \mathrm{m}^{2}$ (Table 1).

Table I Survival (\%) and production $\left(\mathrm{g} / \mathrm{m}^{2}\right)$ of marron fed basal and probiotic diets

\begin{tabular}{|c|c|c|c|c|c|c|}
\hline & \multicolumn{3}{|c|}{ Basal diet } & \multicolumn{3}{|c|}{ Probiotic diet } \\
\hline & I & 2 & 3 & I & 2 & 3 \\
\hline $\begin{array}{l}\text { Initial stocking } \\
\text { (n) }\end{array}$ & 3200 & 3000 & 3200 & 3100 & 3200 & 3200 \\
\hline Total harvest (n) & 1662 & 2287 & 2249 & 2139 & 2472 & 2474 \\
\hline Survival (\%) & 51.94 & 76.23 & 70.28 & 69.00 & 77.25 & 78.16 \\
\hline $\begin{array}{l}\text { Weight harvest } \\
(\mathrm{kg})\end{array}$ & 137.64 & 195.8 & 363.8 & 192.65 & 148 & 241.3 \\
\hline $\begin{array}{l}\text { Average weight } \\
(\mathrm{kg})\end{array}$ & 0.083 & 0.086 & 0.162 & 0.090 & 0.060 & 0.098 \\
\hline $\begin{array}{l}\text { Production }(\mathrm{kg} / \\
\left.\mathrm{m}^{2}\right)\end{array}$ & 0.153 & 0.218 & 0.404 & 0.214 & 0.164 & 0.268 \\
\hline
\end{tabular}

\section{p. Temperature}

The water temperature in each pond fluctuated daily, but greater water temperature $\left({ }^{\circ} \mathrm{C}\right.$ ) fluctuation occurred in November (Figure $5 \& 6$ ). The highest water temperature in marron ponds in average was observed in January and February with an average of $25.61^{\circ} \mathrm{C}$ to $25.84^{\circ} \mathrm{C}$, whereas the lowest $\left(13.05 \pm 1.2^{\circ} \mathrm{C}\right)$ was observed in July. In addition, a very extreme temperature fluctuation was detected on $21^{\text {st }}$ November where the temperature at night ( 2400 hours) ranged between $12.7^{\circ} \mathrm{C}$ to $13.9^{\circ} \mathrm{C}$ but during the day time (1200 hours) jumped to $36.3^{\circ} \mathrm{C}$ to $52.7^{\circ} \mathrm{C}$ which caused high mortality especially in the basal diet fed marron ponds.

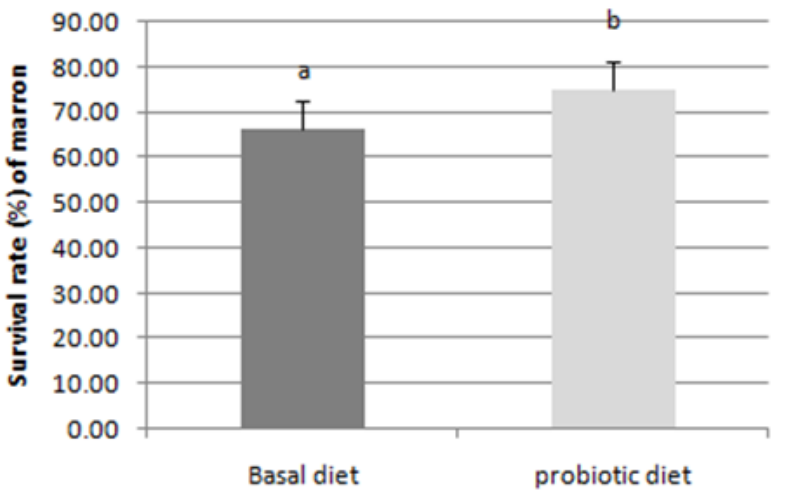

Figure 5 Survival rate (\%) of marron fed basal and probiotic supplemented diets.

*Different letters over bars indicates significantly different at 0.05 .

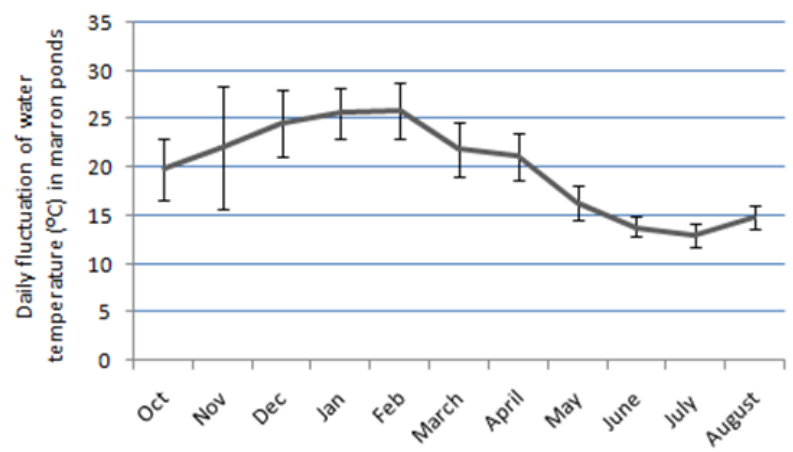

Figure $\mathbf{6}$ The average water temperature in marron ponds during feeding trial.

\section{Discussion}

In aquaculture, the higher immune status of an animal is crucial as the animal is exposed to a series of stress conditions including the natural rhythms of the environment ${ }^{17,33}$ and the link between stress and higher susceptibility to diseases is conclusive. ${ }^{33}$ Therefore, the improved immunity of the aquatic animal ${ }^{1,4,34}$ is particularly important to reduce mortalities which lead to significant economic losses and to ensure a profitable aquaculture operation..$^{35}$ The present in vivo study suggested that customized probiotic $B$. mycoides significantly improved marron immunity and health status (THC, HSi, intestinal bacteria population and GPx enzyme activity), which in turn improved the survival rate of marron.

The THC of marron fed B. mycoides supplemented diets improved significantly showing that the probiotic $B$. mycoides remained effective during the entire feeding trial and was able to play a crucial role in marron immunity. It has been proposed by most authors that the marron origin probiotic candidate is preferred as its efficacy is likely to be highest in the host and environment from where it has been isolated. ${ }^{7,19}$ Improved THC by feeding probiotic diets has also been observed in many crustaceans such as tiger shrimp Penaeusmonodon ${ }^{23}$ western king prawns P.latisulcatus), ${ }^{36}$ shrimps $P$. japonicus ${ }^{37}$ and Litopenaeusvannamei. ${ }^{38}$ Moreover, the haemocytes have been successfully used as an immune indicators in various crustacean such as shrimps ${ }^{39,40}$ lobsters, ${ }^{29,41,42}$ crabs $^{42}$ and crayfishes ${ }^{43,44}$ including marron ${ }^{46,47}$ as the haemocytes are involved in various defence mechanisms including recognition, phagocytosis, encapsulation, storage and release of the proPO system and cytotoxicity. ${ }^{48,49,50}$

It has been documented that the hepatopancreas of crustacean is not just an organ responsible for metabolism but it is an integrated part of immunity. ${ }^{51}$ The hepatopancreas is an important organ for absorption and storage of large amounts of energy particularly lipids and can synthesize digestive enzymes for food digestion. ${ }^{52}$ It has also been used as an indicator of the marrons' condition. ${ }^{30,31}$ As the hepatopancreas also serves as source of various enzymes, the larger hepatopancreas of crayfish could be an indicator of greater digestive enzyme activities. ${ }^{53}$ In the present study, B. mycoides significantly improved HSi of marron compared to HSi of basal diet fed marron both on day 90th and day 160th which suggested that a supplemented probiotic in the marron diet was able to improve the metabolism and energy availability for the animals. These results are in line with Tapia-Paniagua et al. ${ }^{33}$ who suggested that probiotics increases energy availability of animals and thus improve stress tolerance. 
In addition to hepatopancreas, the intestinal bacteria population also plays a significant role in metabolism and immunity. The beneficial bacteria not only protect the animal from the pathogen invasion, but also reflect the nutritional status of the animal. ${ }^{54,55,56}$ The present study demonstrated that $B$. mycoides significantly improved the intestinal bacteria population of the marron and also that there was an increase in bacteria population both in basal and probiotic diets fed marron as the marron size increased on day 160th. Ringøet al. ${ }^{57}$ suggested that there is a progressive increase of intestinal bacteria population of small intestines to larger intestines of aquatic animals. Modulation of the intestinal bacteria population have also been demonstrated in many groups of aquatic animals such as Atlantic $\operatorname{cod}^{58}$ Mediterranean teleosts ${ }^{59}$ and Salmonids. ${ }^{2}$

GPx is another immune parameter of marron, which was improved by feeding with a probiotic supplemented diet. The GPx of marron fed with a probiotic diet was significantly higher than the GPx of basal diet fed marron. Our previous study also revealed a progressive increase of GPxtail muscle tissue of marron with time from one to four weeks feeding. Improved antioxidant enzyme activity by feeding with probiotics have been detected in shrimp Litopenaeusstylirostris. ${ }^{60} \mathrm{GPx}$ enzyme activity plays a crucial role in maintaining cellular homeostasis of crayfish ${ }^{61}$ protects the body from oxidation by free radicals ${ }^{62}$ which can cause cellular damage and oxidative stress. ${ }^{63}$ The GPx activity has also been detected higher in haemocyte of marron. ${ }^{64}$ In addition, probiotics especially lactic acid bacteria exhibit various antioxidant activity which is capable of limiting excessive amounts of reactive radicals in vivo and thus potentially contributes in preventing and controlling several diseases associated with oxidative stress. ${ }^{65}$

Survival rate and growth are critically important for a profitable aquaculture practices. In the present study, the average survival rate (74.8\%) of B. mycoides diet fed marron was significantly higher than the survival rate $(66.2 \%)$ of basal diet fed marron as the probiotic was able to improve immunity and stress tolerance of marron when the culture condition extreme. An extreme fluctuation of water temperature on the $21 \mathrm{st}$ of November ranged between $12.78^{\circ} \mathrm{C}$ to $13.94^{\circ} \mathrm{C}$ at night (2400 hours) and between $36.29^{\circ} \mathrm{C}$ to $52.72^{\circ} \mathrm{C}$ during the day time (1200 hours) in the marron ponds triggered high marron mortality on that day and the following days. However, higher immune status particularly the HSi of probiotic fed marron suggested the animals were more adaptable to this chronic environmental stress situation which resulted in a higher survival rate compared to the basal diet fed marron. Jussila et al. ${ }^{46}$ observed a decreased HSi of marron during a post simulated transport stress test, which suggested that high energy utilization (hepatopancreas) induced by this stress conditions. ${ }^{66} \mathrm{In}$ addition, high mortality in basal diet marron pond resulted in more food available for survive marron, thus

Though immunity and the health status of marron given a probiotic fed diet were significantly higher than basal diet fed marron as described above, the average pond production was still relatively low. This could be partly attributed to a broad spectrum of juvenile size and/quality and their sources used at the initial stocking of the experimental ponds. The basal diet fed ponds were initially stocked with the juveniles produced from the same experimental ponds, whereas most of the juveniles for the probiotic fed marron ponds were obtained from the non-experimental ponds and out sourced and were relatively smaller in size than the juvenile sizes of basal diet fed marron. Lack of juvenile's sources at initial stocking time contributed to the relatively larger variations in sizes and quality.
Therefore, further study is required by using only one source of equal sized juveniles as an initial stocking to evaluate the performance of probiotic diets on marron in commercial marron farms. A comparable size of animal from treatments groups is recommended by some authors when measuring a particular parameters as several parameters vary greatly according to animal size or organs such as bacteria density and microvilli of similar size GIT. ${ }^{55,67}$

\section{Conclusion}

In summary, the customized marron origin probiotic $B$. mycoides worked effectively in vivo (commercial marron farm) as indicated by a significant improvement of marron immunity and health status (THC, GPx enzyme activity, intestinal bacteria population and HSi) which in turn enhanced survival rates when compared to basal diet fed marron.

\section{Acknowledgements}

None.

\section{Funding}

None.

\section{Conflicts of interest}

The author declares that there are no conflicts of interest.

\section{References}

1. Nayak SK. Probiotics and immunity: A fish perspective. Fish shellfish immunol. 2010;29(1):2-14.

2. Merrifield, Dimitroglou A, Foey A, et al. The current status and future focus of probiotic and prebiotic applications for salmonids. Aquaculture. 2010;302(1-2):1-18

3. Newaj-Fyzul A, Al-Harbi AH, Austin B. Review: Developments in the use of probiotics for disease control in aquaculture. Aquaculture. 2014;431:1-11.

4. Hai. The use of probiotics in aquaculture. Journal of Applied Microbiology. 2015;119:917-935.

5. Sihag RC, Sharma P. Probiotics: the new ecofriendly alternative measures of disease control for sustainable aquaculture. Journal of Fisheries and aquatic science. 2012;7(2):72-103.

6. Tinh NTN, Dierckens K, Sorgeloos P, et al. A review of the functionality of probiotics in the larviculture food chain. Mar Biotechnol. 2008;10(1):1-12.

7. Verschuere L, Rombaut G, Sorgeloos P, et al. Probiotic Bacteria as Biological Control Agents in Aquaculture. Microbiol Mol Biol Rev. 2000;64(4)655-671.

8. Balcázar JL, Blas ID, Ruiz-Zarzuela I, et al. The role of probiotics in aquaculture. Veterinary microbiology. 2006;114(3-4):173-186.

9. Kesarcodi-Watson A, Kaspar H, Lategan MJ, et al. Probiotics in aquaculture: The need, principles and mechanisms of action and screening processes. Aquaculture. 2008;274(1):1-14.

10. Vine N, Leukes WD, Kaiser H, et al. Competition for attachment of aquaculture candidate probiotic and pathogenic bacteria on fish intestinal mucus. Journal of Fish Diseases. 2004;27(6):319-326.

11. Sahu MK, Swarnakumar NS, Sivakumar K, et al. Probiotics in aquaculture: importance and future perspectives. Indian J Microbiol. 2008;48(3):299-308. 
12. Wong S, Rawls JF. Intestinal microbiota composition in fishes is influenced by host ecology and environment. Molecular Ecology. 2012;21:3100-3102.

13. Mickeniene. Bacterial Flora in the Digestive tract of native and Alien Species of Crayfish in Lithuania. Freshwater Crayfish 12. Proceeding of the 12th symposium International Association of Astacology, Augsburg, Bavaria, Germany. 1998;279-287.

14. Ringø E, Myklebust R, Mayhew TM, et al. Bacterial translocation and pathogenesis in the digestive tract of larvae and fry. Aquaculture. 2007;268(1-4):251-264.

15. Burr G, Gatlin D. Microbial Ecology of the Gastrointestinal Tract of Fish and the Potential Application of Prebiotics and Probiotics in Finfish Aquaculture. Journal of the World Aquaculture Society. 2005;36(4):425436.

16. Gatesoupe FJ. The use of probiotics in aquaculture. Aquaculture. 1999; 180, 147-165

17. Rollo A, Sulpizio R, Nardy M, et al. Live microbial feed supplement in aquaculture for improvement of stress tolerance. Fish Physiol Biochem. 2006;32:167-177.

18. Hai Buller N, Fotedar R. The use of customised probiotics in the cultivation of western king prawns (Penaeus latisulcatus Kishinouye, 1896). Fish \& Shellfish Immunology. 2009;27(2):100-104.

19. O'sullivan DJ. Screening of intestinal microflora for effective probiotic bacteria. Agricultural Food and Chemistry. 2001;49:1751-1760.

20. Ambas I, Buller N, Fotedar R. Isolation and screening of probiotic candidates from marron, Cherax cainii (Austin, 2002) gastrointestinal tract (GIT) and commercial probiotic products for the use in marron culture. Journal of Fish Diseases. 2015;38(5):467-476.

21. Ambas I, Suriawan A, Fotedar R. Immunological responses of customised probiotics-fed marron, Cherax tenuimanus, (Smith 1912) when challenged with Vibrio mimicus. Fish \& shellfish immunology. 2013;35(2):262-270.

22. Ambas I, Fotedar R, Buller N. Bacillus mycoides Improves Health of Gastrointestinal Tract in Marron (Cherax cainii, Austin 2002). J Aquac Mar Biol. 2015;2:1-7.

23. Rengpipat S, Rukpratanporn S, Piyatiratitivorakul S, et al. Immunity enhancement in black tiger shrimp (Penaeus monodon) by a probiont bacterium (Bacillus S11). Aquaculture. 2000;19(4):271-288.

24. Thompson $\mathrm{J}$, Gregory $\mathrm{S}$, Plummer $\mathrm{S}$, et al. An in vitro and in vivo assessment of the potential of Vibrio spp. as probiotics for the Pacific White shrimp, Litopenaeus vannamei. Journal of Applied Microbiology. 2010;109(4):1177 -1187.

25. Salma W, Zhou Z, Wang W, et al. Histological and bacteriological changes in intestine of beluga (Huso huso) following ex vivo exposure to bacterial strains. Aquaculture. 2011;314(1-4):24-33.

26. Hai, Fotedar R. Comparison of the effects of the prebiotics (Bio-Mos ${ }^{\circledR}$ and $\beta-1,3-\mathrm{D}-$ glucan) and the customised probiotics (Pseudomonas synxantha and P. aeruginosa) on the culture of juvenile western king prawns (Penaeus latisulcatus Kishinouye, 1896). Aquaculture. 2009;289(3-4):310-316.

27. Hai Fotedar R, Buller N. Selection of probiotics by various inhibition test methods for use in the culture of western king prawns, Penaeus latisulcatus (Kishinouye). Aquaculture. 2007;272(1-4):231-239.

28. Buller NB. Bacteria from Fish and Other Aquatic Animals: A Practical Identification Manual. CABI Publishing, Oxford shire, UK. 2004.

29. Fotedar S, Tsvetnenko E, Evans L. Effect of air exposure on the immune system of the rock lobster Panulirus cygnus. Marine and Freshwater Research. 2001;52(8):1351-1355.
30. Jussila J. Carapace mineralisation and hepatopancreatic indices in natural and cultured population of marron (Cherax tenuimanus) in Western Australia. Marine and Freshwater Research. 1997;48(1):67-72.

31. Fotedar R. Nutrition of marron, Cherax tenuimannus (Smith) under different culture environments - a comparative study (Unpublished) PhD thesis. Perth, Western Australia: Curtin University of Technology. 1998. p.174.

32. Rotruck JT, Pope Al, Ganther He, et al. Selenium: biochemical role as a component of glutathione peroxidase. Science. 1973;179(4073):588590

33. Tapia-Paniagua ST, Vidal S, Lobo C, et al. The treatment with the probiotic Shewanella putrefaciens Pdp11 of specimens of Solea senegalensis exposed to high stocking densities to enhance their resistance to disease. Fish \& Shellfish Immunology. 2014;41(2):209221.

34. Ridha MT, Azad IS. Effect of autochthonous and commercial probiotic bacteria on growth, persistence, immunity and disease resistance in juvenile and adult Nile tilapia Oreochromis niloticus. Aquaculture research. 2015;47(9):1-11.

35. Bachere E. Shrimp immunity and disease control - Introduction. Aquaculture. 2000;191:3-11.

36. Hai, Buller N, Fotedar R. Effect of Customized Probiotics on the Physiological and Immunological Responses of Juvenile Western King Prawns (Penaeus latisulcatus Kishinouye, 1896) Challenged with Vibrio harveyi. Journal of Applied Aquaculture. 2010;22:321-336.

37. Zhang Q, Tan B, Mai K, et al. Dietary administration of Bacillus (B. licheniformis and B. subtilis) and isomaltooligosaccharide influences the intestinal microflora, immunological parameters and resistance against Vibrio alginolyticus in shrimp, Penaeus japonicus (Decapoda: Penaeidae). Aquaculture research. 2011;42(7):943-952.

38. Li, Tan B, Mai K. Dietary probiotic Bacillus OJ and isomaltooligosaccharides influence the intestine microbial populations, immune responses and resistance to white spot syndrome virus in shrimp (Litopenaeus vannamei). Aquaculture. 2009;291:35-40.

39. Lorenzon S, Francese M, Smith VJ, et al. Heavy metals affect the circulating haemocyte number in the shrimp Palaemon elegans. Fish \& shellfish immunology. 2001;11(6):459-472.

40. Van De Braak, Botterblom Mha, Liu W, et al. The role of the haematopoietic tissue in haemocyte production and maturation in the black tiger shrimp (Penaeus monodon). Fish \& shellfish immunology. 2002;12(3):253-272.

41. Lorenzon S, Giulianini PG, Martinis M, et al. Stress effect of different temperatures and air exposure during transport on physiological profiles in the American lobster Homarus americanus. Comp Biochem Physiol A. 2007; 147(1):94-102.

42. Jussila J, Jago J, Tsvetnenko E, et al. Total and differential hemocyte counts in western rock lobsters Panulirus cygnus George. under postharvest stress. Mar Freshwater Res. 1997;48(8):863-868.

43. Lorenzon PG, Giulianini S, Libralato M, et al. Stress effect of two different transport systems on the physiological profiles of the crab Cancer pagurus. Aquaculture. 2008;278(1-4):156-163.

44. Persson M, Cerenius L, Soderhall K. The Influence of Haemocyte Number on The Resistance of The Freshwater Crayfish, Pasifastacus leniusculus Dana, to The Parasitic Fungus, Aphanomyces astacii. Journal of fish diseases. 1987;10(6):471-477.

45. Soderhall K, Vey AMR. Haemocytes lysate enhancement of fungal spore encapsulation by crayfish hemocytes. Dev Comp Immunol. 1984;8(1):23-29. 
46. Jussila J, Paganini M, Mansfield S, et al. On physiological responses, plasma glucose, total hemocyte count and dehydration, of marron Cherax tenuimanus (Smith) to handling and transportation under simulated conditions. Freshwater Crayfish. 1999;12:154-167.

47. Sang HM, Ky LT, Fotedar R. Dietary supplementation of mannan oligosaccharide improves the immune responses and survival of marron, Cherax tenuimanus (Smith, 1912) when challenged with different stressors. Fish \& shellfish immunology. 2009;27, 341-348.

48. Soderhall K, Cerenius L. Crustacean immunity. Annu Rev Fish Dis. 1992;2:3-23.

49. Johansson MW, Keyser P, Sritunyalucksana K, et al. Crustacean haemocytes and haematopoiesis. 2000;191(1-3):45-52.

50. Sritunyalucksana K, Soderhall K. The proPO and clotting system in crustaceans. Aquaculture. 2000;191:53-69.

51. Röszer T. The invertebrate midintestinal gland ("hepatopancreas") is an evolutionary forerunner in the integration of immunity and metabolism. Cell Tissue Res. 2014;358(3):685-695.

52. Wang W, Wu X, Liu Z, et al. Insights into Hepatopancreatic Functions fo Nutrition Metabolism and Ovarian Development in the Crab Portunus trituberculatus: Gene Discovery in the Comparative Transcriptome of Different Hepatopancreas Stages. PLoS ONE. 2014;9(1): e84921.

53. Hammer HS, Bishop CD, Watts SA. Activities of three digestive enzymes during development in the crayfish Procambarus clarkii (Decapoda). Journal of the Crustacean Biology. 2000;20(4):614-620.

54. Ringø E, Salinas I, Olsen R, et al. Histological changes in intestine of Atlantic salmon (Salmo salar L.) following in vitro exposure to pathogenic and probiotic bacterial strains. Cell Tissue Res. 2007;328(1):109-116.

55. Denev S, Staykov Y, Moutafchieva R. Microbial ecology of the gastrointestinal tract of fish and the potential application of probiotics and prebiotics in finfish aquaculture. Int Aquat Res. 2009;1(1):1-29.

56. Gaggìa F, Mattarelli $\mathrm{P}$, Biavati $\mathrm{B}$. Review Probiotics and prebiotics in animal feeding for safe food production. International Journal of Food Microbiology. 2010;141:S15-S28.

57. Ringø E, Olsen RE, Mayhew TM, et al. Electron microscopy of the intestinal microflora of fish. Aquaculture. 2003;227(1-4):395-415.
58. Lazado CC, Marlowe C, Caipang A. Review Atlantic cod in the dynamic probiotics research in aquaculture. Aquaculture. 2014;424-425:53-62.

59. Dimitroglou A, Merrifield DL, Carnevali O, et al. Microbial manipulations to improve fish health and production - A Mediterranean perspective. Fish \& Shellfish Immunology. 2011;30(1):1-16.

60. Castex M, Pierrette L, Nelly W, et al. Effect of probiotic Pediococcus acidilactici on antioxidant defences and oxidative stress of Litopenaeus stylirostris under Vibrio nigripulchritudo challenge. Fish \& shellfish immunology. 2010;28(4):622-631.

61. Borković SS, Pavlović SZ, Kovačević TB, Antioxidant defence enzyme activities in hepatopancreas, gills and muscle of Spiny cheek crayfish (Orconectes limosus) from the River Danube. Comparative Biochemistry and Physiology, Part C. 2008;147(1):122-128.

62. Chiu ST, Hsieh SL, Yeh SP, et al. The increase of immunity and disease resistance of the giant freshwater prawn, Macrobrachium rosenbergi by feeding with selenium enriched-diet. Fish Shellfish Immunol. 2010;29(4):623-629.

63. Parrilla-Taylor DP, Zenteno-Savín T. Antioxidant enzyme activities in Pacific white shrimp (Litopenaeus vannamei) in response to environmental hypoxia and reoxygenation. Aquaculture. 2011;318;(34):379-383

64. Nugroho RA, Fotedar R. Comparing the effects of dietary selenium and mannan oligosaccharide supplementation on the growth, immune function, and antioxidant enzyme activity in the cultured marron Cherax cainii (Austin, 2002). aquacult int. 2013.

65. Amaretti A, Nunzio MD, Pompei A, et al. Antioxidant properties of potentially probiotic bacteria: in vitro and in vivo activities. Appl Microbiol Biotechnol. 2013;97(2)809-817.

66. Cruz PM, Ibanez AL, Hermosillo OAM, et al. Use of Probiotics in Aquaculture. International Scholarly Research Network. ISRN Microbiology. 2012;13.

67. Cerezuela R, Guardiola FA, Meseguer J, et al. Increases in immune parameters by inulin and Bacillus subtilis dietary administration to gilthead seabream (Sparus aurata L.) did not correlate with disease resistance to Photobacterium damselae. Fish \& shellfish immunology. 2012;32(6):1032-1040. 